Pakistan Journal of Humanities \& Social Sciences Research

Volume No. 02, Issue No. 01(June, 2019)

\title{
A POLITICAL ROADMAP OF MODERN CHINA AND ITS TRANSFORMATION THROUGH ECONOMIC, POLITICAL AND EDUCATIONAL DEVELOPMENT (2011-2018)
}

\author{
Nargis Zaman* \& Dr. Farah Khan**
}

\begin{abstract}
The collapse of empires and the rise of nations was a distinguishing political shift in the making of the contemporary modern world. The surge of China is also portrayed by drastic economic and political transition of the $21^{\text {st }}$ century. With the commencement of communist revolution in 1949, People's Republic of China was established. The economy and politics of the nation have encouraged numerous times, largely because of the leaders and their massively surprising objectives. Since then, Beijing has made remarkable progress in its political and economic growth. Being the most influential leader, Mao Zedong put China in the right direction by replacing old system and introducing "Great leap Forward" to organize agriculture. He began "Cultural Revolution" to revitalize the innovative spirit of the Chinese people. After Mao's death, other powerful leader Deng Xiaoping ruled China and significantly developed good relations with other states and focused China's economy. Xi jinping who is the most powerful president after Deng Xiaoping brought improvement in education sector, launched financial reforms and unlocked China to the globe to attract foreign investment and energized private sector, flourish economy and make china politically strong. Beijing has been vigorously struggled and involved in economic activities by surpassing Japan in 2008 and became world's second largest economy from 2011. Xi Jinping, after consolidation of powers announced bring huge reforms in connection with Grand strategy of "One belt One Road" that would connect china to Asian and European countries through

*Lecturer, Department of Political Science Women University Mardan

**Assistant Professor, Women University Mardan
\end{abstract}


inland and sea routes. Once it executes in full term, China will rule the world being economic and political giant of the world.

Key Words: Communist Revolution, Economic reforms, Educational reforms; Political developments, Grand strategy, One belt one Road

\section{INTRODUCTION}

The History of the affluent states round the world will tell that their achievements were only possible after their never ending struggle and the buoyancy of their countrymen led by the proficient leaders. If we thoroughly analyze the economy, the political roadmap and the way of life Chinese people, we would be able to know that the people republic of China started long journey of their development from scratch and aims beyond skies as the limit. Since 1949, society of china has undergone a loud change in its socio-economic, political and cultural realms. Under the leadership of China's Communist party, the Chinese people were dropped downward for the large scale of national experiments. Among such experiments, the Great Leap Forward campaign of Mao Zedong (1958-60) for communism, the social turmoil of the Great Proletariat Cultural Revolution from 1966-1976, the massive economic shift towards market

${ }^{1}$ Department of Political science Women university Mardan, KP oriented social economy from a centrally-planned economy in the post-1978 period. It was the second stage of the revolution headed by Deng Xiaoping, who was also one the leaders of the revolution of 1949, that led to the building of modern China. With its remarkable scale of economic growth from the last four decades, China also focused on the betterment of the lives of common masses. Since the reforms and opening up,improvement in living standards of the common people is, therefore, the most important goal and achievement of China. This has been a great accomplishment for a country with large numbers of poor people streaming into its cities, many living initially in conditions of abject misery.

More importantly, succeeding leaders of China recognized that political stability and economic development were entangled. 
While economic development had been remain on their top priority, China has avoided all kinds of conflicts and kept itself away from fights and issues. Economics and politics are interrelated, In the present-day study of China, one cannot really separate economic reform from political change. People living in China in 1978 would not know the degree of civic and political freedom in the country today. New social forces released by China's economic reforms have been transforming the country's political landscape. Other factors are also involved in the China's social and economic development.China has made huge investments in its education sector. The education system of China has been improving over the time and returning back to its preCultural Revolution state since the beginning of reforms in economic sector. New high standard Universities were opened, and opportunities were given to the students to take examinations and to enter into universities and the graduate schools. In order to improve education in china, the ministry of education in china supported different cooperative programs with foreign educational institutions from 1985 to 2016. Apart from that, individual universities were given the choice and liberty to invite foreign scholars and intellectuals to lecture in the Chinese universities. The Students are allowed to go abroad for higher studies, university courses have been designed according to the new circumstances, skills in the modern and new languages, particularly in English, improved so quickly with the passage of time, and now texts in English began to be adopted.

China has made implausible developments from the last 69 years .The glaring example in this regard is that China became the world second largest economy since 2008 , wherein the lives of round about 2 billion people have been improved. While the open door policy and the china amalgamation with the rest of the world has never been that much closer than today.The china long successes story and incredible developments has entered this nation into a new era for turning itself into modern socialist country in all aspects. The china reformation and opening up after the second revolution has greatly contributed and deeply influenced the world, it contributed to the well-being of the people around the world but also developed itself to the great extent. 
China is determined Under the leadership of the President Xi Jinping to construct a modern economic system, and to give momentum to the innovation-driven development strategy.

The (BOR) belt and road initiative of China is historical achievement of China to connect China with the external world. The China Pakistan Economic Corridor (CPEC) in Pakistan is considered as a game changer that is going to bring stability to the economic sector in both countries and bring employment opportunities to the people of both the country. China is a very challenging country one can define. The common perception across the world about China as a rising hegemony, a global economic power, the next superpower. Although it is a fact that over the past 30 years, China has experienced an amazing development and transformation in its political ,economic and educational status.Rather than point out "one China" as a one entity, this study would tend to explore three totally different Chinas that we see nowadays. This study would provide a full image of China journey from the status of empire to the major world power. China became the second largest economy of the world over the past 30 years, it tipped to overtake America in educational and economic sector within the next decade.

The main objectives of this study is to examine that how political, economic and educational factors contributed to the transformation of china.

\section{Methodology}

The research is quite qualitative empirical based on observation and description. The paper obtained data from books, articles, research journals, after which it is analyzed qualitatively. Empirical qualitative analysis provides rich and profound circumstantial data on the China developmental journey. And an in depth analysis of the literature carried out. For this purpose, the data collection and analysis for the study has done recently during 2011-2018. Both primary and secondary data taken into account to collect information. These include online videos, reports, news and research studies. Secondary sources comprised of books, journals, magazines, etc. 
Results and data Analysis

Political Transformation in China (2011-2018)

In 1911 the fall of the dynasty of Manchu entail the creation of a republic, but in no time China was crumble into the warlordism. The Kuomintang in the 1920s, Nationalist, regime started a process of reintegration, and within a decade it made remarkable progress. After the Japanese aggression and revolution of the communists, contributed to the failure of Nationalist;, China again divided after World War II during the civil war (Barnett, 1986). In 1949 The triumph of the Chinese Communist Party (CCP) was a major watershed. The new regime rapidly established an effective central government resulted the reunification of the country for the first time in the twentieth century. In the mid 1950s, China was appeared to be on the doorstep of progress and economic growth for a short period of time, but Mao, by the end of that decade, following his own vision of the egalitarian society, adopted his radical policies and reforms and gave a call for "continual revolution." In the late 1950, the Great Leap Forward bring grievous economic depression, and in the 1960s the Cultural Revolution resulted into the collapse of the country's political system (Barnett,1986). China set a new course of reforms in economic and political sector by the end of 1978 which proved turning point in the history of China .

President Xi has burge on the party power in his term even he alleviate his own political powers. Xi after assuming the office in 2013 ,he started an anti-corruption campaign against the corrupt practices. Till the end of 2016, 150 higher-level and 120,000 lower-level officials had been condemned by the campaign (Ping, 2018).The 6th plenum in 2016, thecentral committee of the 18th Party (hereafter 6th plenum) formed some new sets of agencies, committees of supervision, to fortify the party's anti-corruption work. These new and the most influentialcommittees under the party control, have monitored that government structures which enforce the anti-corruption, thus strengthened the control of the party (Horsley, 2018).

The anti-corruption campaign has consolidated the institutional change in China. The institutional reforms in China has from the 
last five years pressurized the officials which increase the power of local Party leaders. A set of regulations and policies were issued at the 6th plenum which emphasize on the role of meetings called "democratic life meetings" which made it mandatory for the state officials to attend at least one meeting a year (Denyer, 2018). Themain objective of holding these meetings for the officials to manage public affairs and perform self criticism.Sub national governments perform myriad of important government functions, including building infrastructure, developing the local economy and administering social welfare programs. Local governments in China are far more fiscally decentralized than in many other countries. In 2017, sub national governments generated 53.4 per cent of total government revenues and covered 63.2 per cent of total government expenditures (Weightman, 2018). In comparison, sub national governments in OECD countries (which tend to be more decentralized than post-communist and developing countries) generate average local expenditures of around 32 per cent and average local revenues of around 19.1 per cent which contributed a lot to the well being of the Chinese people

\section{More mentions of well-being and reforms}

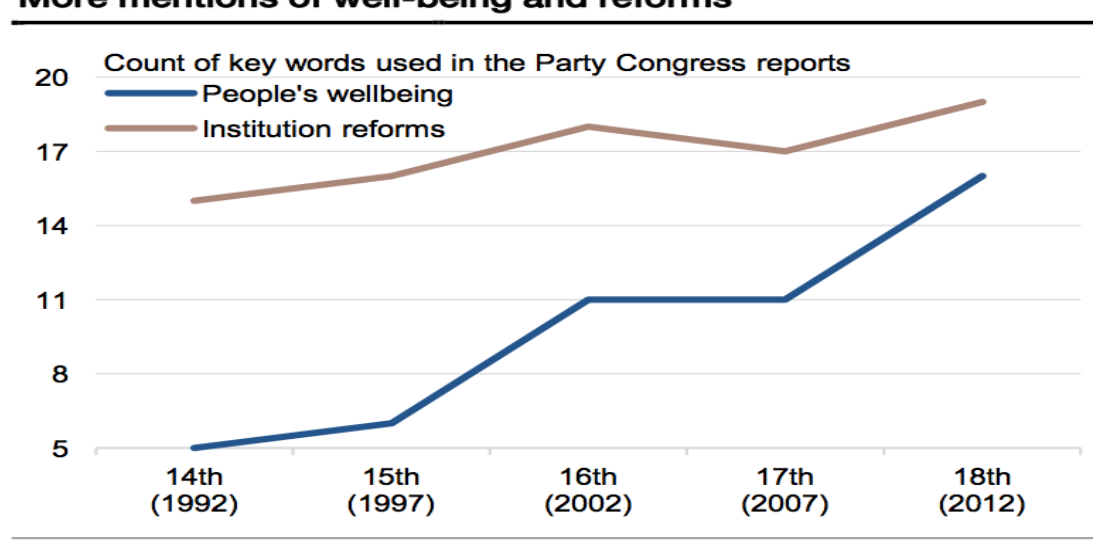

Source: SG Cross Asset Research/Economics

Figure 1

The relationship between central and local governments under xi jingping in the context of China's growing social demands most citizens are relatively complacent with the current conditions in the country and express a "high degree of trust in the ability of 
the central government to manage the problems the country faces"(Shambaugh 2018).President Xi had grasped and consolidated his power than $\mathrm{Hu}$ and Jiang had ever held. In October $2017 \mathrm{Xi}$ broke precedent at the nineteenth party congress by not promoting a successor-in-training. The National People's Congress in march2018 amended the constitution to put an end to the two-term limit for the xi Jingping. President Xi hasgrabbed all the party powers. The Party has alsoclaimed the authority over economic policy that it delegated to the state starting in the 1980s. The 2017 Party Congress promulgated that "East-West NorthSouth the Party is leading everything(Zhou 2011). Heads of government bodies now regularly report to the Politburo Standing Committee. This consolidation of power will bring the center control and will bring long lasting benefits to Chinese economy and institutional building as adopted by Mao zidongPresident Xi Jinping, the most powerful leader since Mao Zedong brings massive reforms in the political and institutional spheres. under xi jingping people were given greater economic freedom, more autonomy, and stronger property rights, resulting China's rise as an economic giant, they will have a better chance of creating a harmonious and prosperous society (Miller,2016).

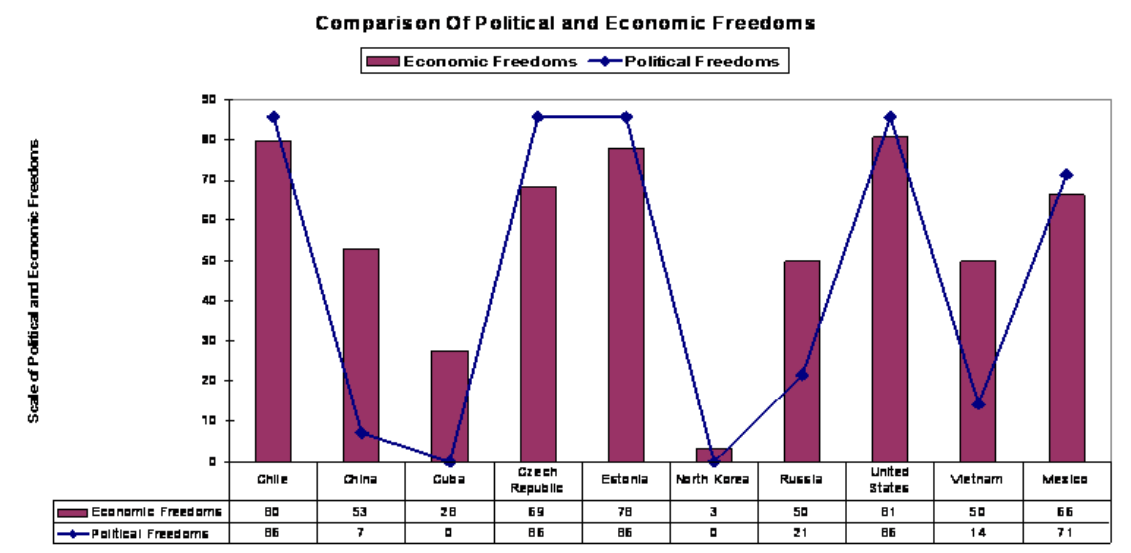

Figure 2

Under $\mathrm{Xi}$, who serves concurrently as the Chinese Communist Party (CCP) General Secretary and the chair of the Central Military Commission (CMC), China has witnessed a striking consolidation of power. This consolidation encompasses three 
important trends. First, central authorities have accrued political power at the expense of bureaucratic ministries and local and provincial governments. An ambitious intergovernmental fiscal reform program will augment the role of the central government. Second, the CCP has dramatically dilated its powers, generally at the expense of the government and other organizations. In March 2018 a major reform plan was publicized which transferred responsibilities from various government ministries to party organizations. As one example, management of all films, media, and publications has been transferred from a government office to the CCP's Propaganda Ministry. Third, the central leadership has undertaken measures to foster the central authority the central leadership has undertaken certain measures (Heath 2018). In March 2018, the National People's Congress, China's national legislature, voted nearly unanimously to amend the constitution to remove presidential term limits

Two complete election cycles at the village level has given a chance to China's 860 million rural inhabitants to replace local Communist bosses with more proficient and less corrupt leaders. CCP recruitment of these newly elected officials, many of them non-Communists who defeated Communists at the polls, is revitalize the party and reinvigorating its support at the grass roots. The party still is on its journey to reestablish its moral authority, but its leaders presume that they are making progress(Landry, 2017)

\section{Economic development in China (2011-2018)}

Since the beginning of market reforms in 1978, China has moved from a centrally-planned to a more market-based economy and has undergone rapid social and economic development. The growth of GDP has averaged about 10 percent a year-which is the fastest sustained expansion in history by a major economy -and as a result more than 800 million people has been lifted out of poverty.By 2015,China reached all the Millennium Development Goals (MDGs) and made an important contribution to the achievement of the MDGs globally. Although China's GDP growth has showed gradually and slowly since 2012 but by current global 
standards, it is still impressive (Barro, 2016).Azam ( 2019), and Muhammad et al. (2019) mentions that China is successfully going towards the accomplishment of sustainable economic development which is the goal of every country in the world.

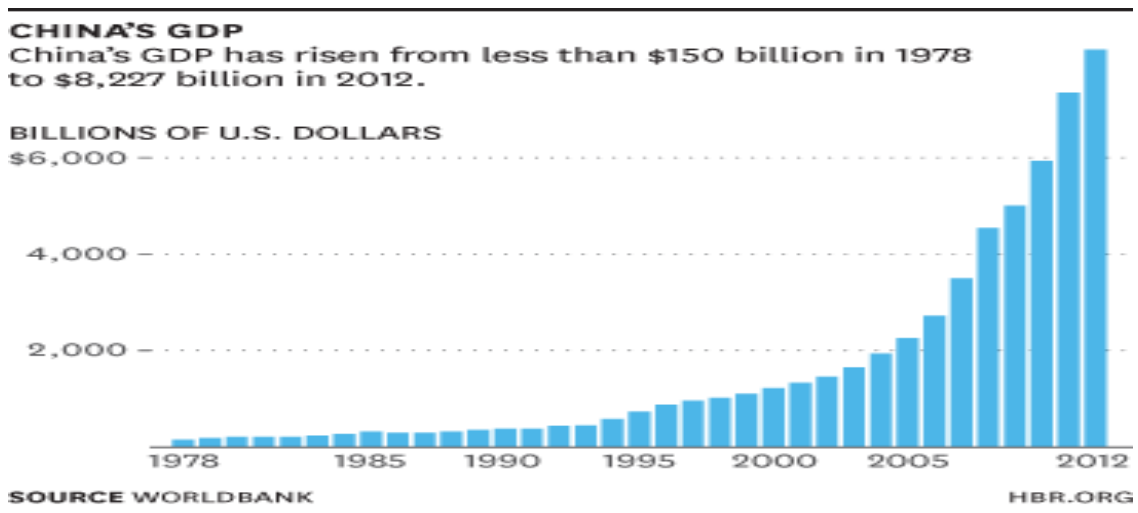

Figure 3

Figure 3 show that China is the second largest economy with a population of 1.3 billion and is increasingly playing a crucial and leading role in development in the global economy. Since the global financial crisis of 2008 and especially from 2013 to 2018, China has been the main single contributor to world growth (Cai, 2016).

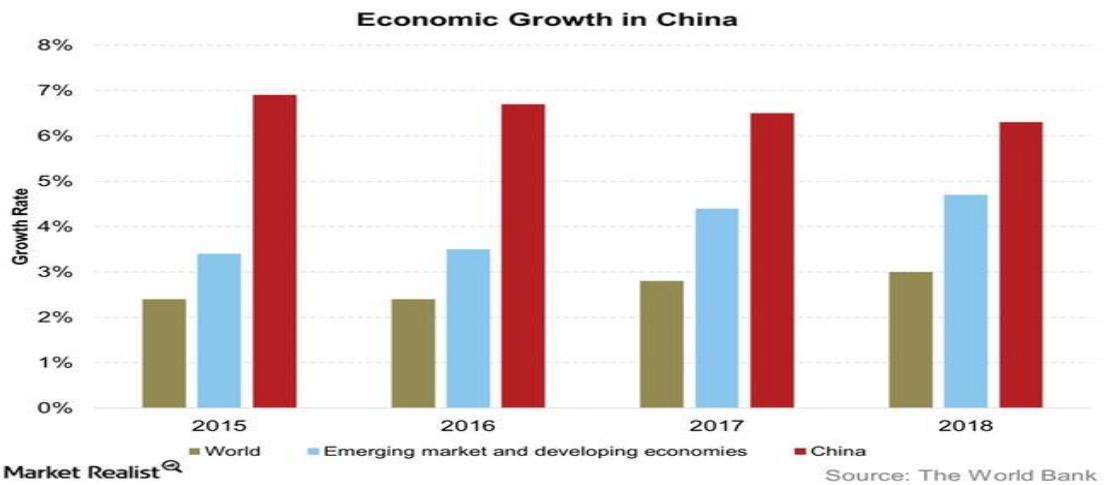

Figure 4 
Since the beginning of economic reforms, the economy of China has grown faster than during the pre-reform period to a great extent and thus has avoided major economic disruptions. From the period of 1979 to 2016,the annual real GDP of China averaged 9.6\%. This has meant that China has been able to more than double the size of its economy on average in real terms every eight years (Goh ,2016).The government of China responded by enacting a $\$ 586$ billion economic stimulus package (approved in November 2008), whose aim was to fund infrastructure and to loosen monetary policies in order to increase bank lending. Such policies made it possible for China to effectively withstand the impacts of the sharp global fall in demand for Chinese products. China's real GDP growth averaged 9.7\% from 2008 to 2010 while in 2010 to $6.7 \%$ and in 2016 (although it rose to 6.9\% in 2017) (Cai ,2013).

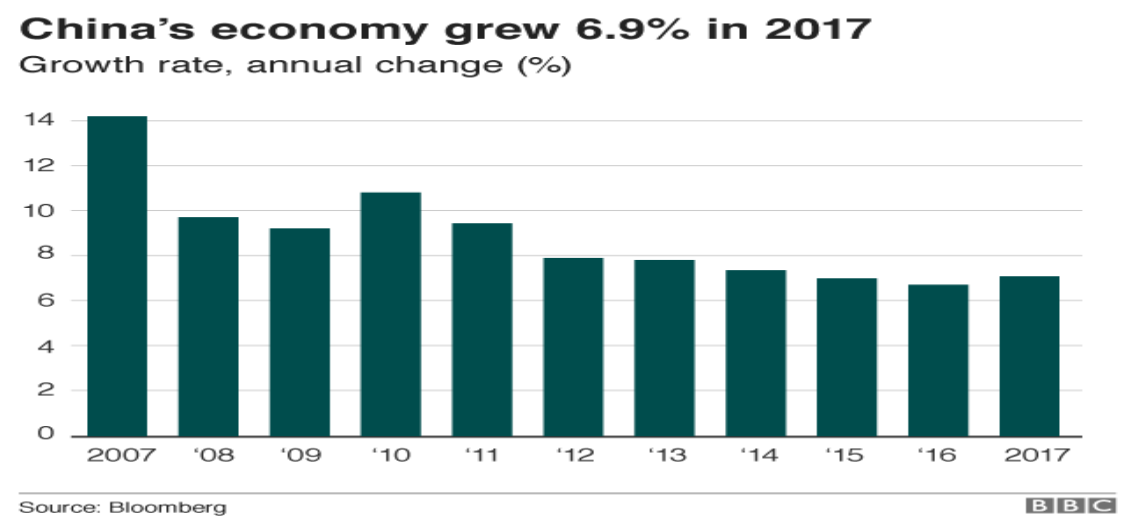

\section{Figure 5}

China's growth miracle can be viewed as the most impressive, lasting, and complex, over the past three decades, in terms of institutional changes and constraint conditions in the history of economic growth, which is generally appreciated by prestigious international organizations and economists. The graph given below will show China's GDP growth from 2013 to 2018 across the world. Due to the open door policies and the positive initiatives in the economic circle of the Chinese leadership, this growth is exceptional and unprecedented (Yu, 2016). 


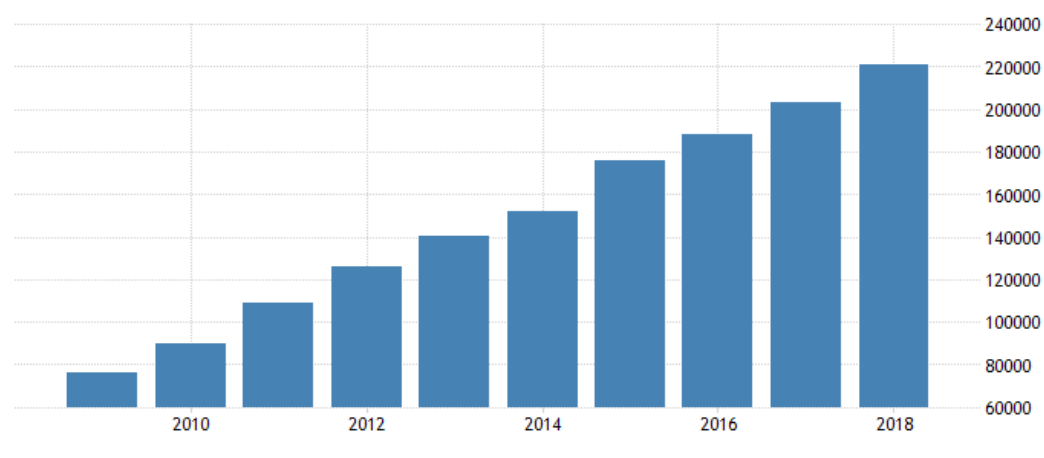

\section{Figure 6}

However, in 2013, an important strategy introduced by the President of Beijing, Xi Jinping, sprung the idea of "Silk Road Economic Belt" as part of the OBOR initiative at Kazakhstan. OBOR is an impressive developmental strategy of infrastructure and connectivity whose emphasis is on the integration of the large parts of the world mainly Eurasia. It entails two main routes: "Silk Road Economic Belt" (SERB)over land and "Maritime Silk Road" (MSR) through waterways (Freeman, 2016).

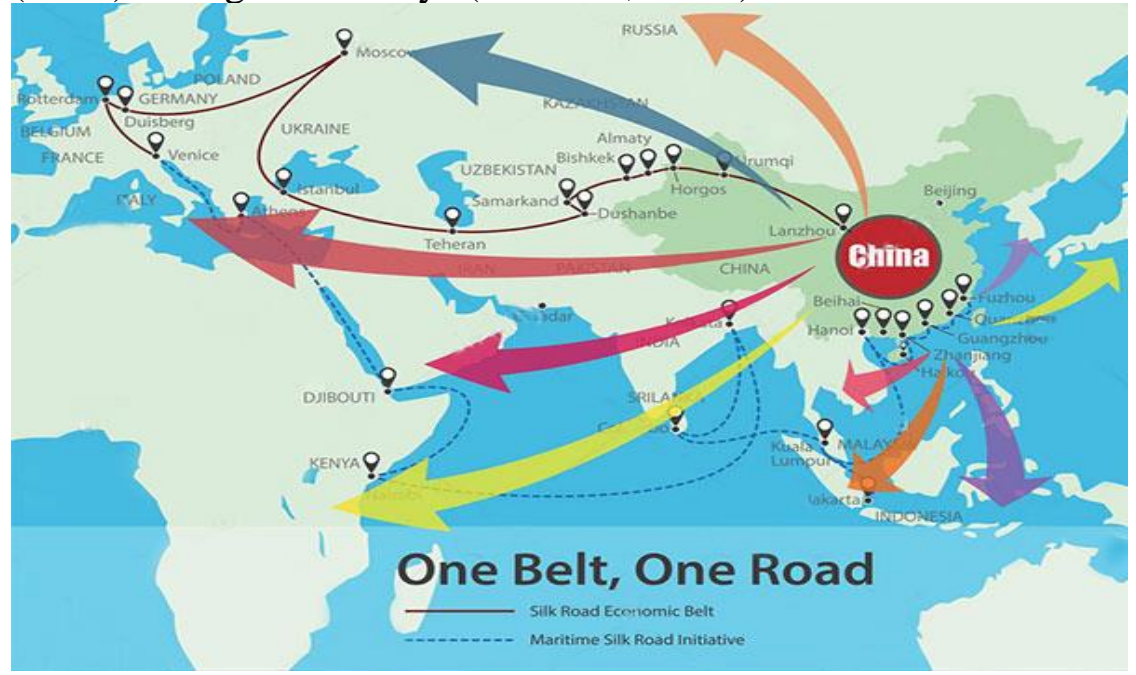

\section{Figure 7}

The utmost priority of the Belt Road initiative is economic integration which through various means like internalization of 
Renminbi (RMB) for business and investment, exciting monetary cooperation, promising financial policy coordination, constructing regional fiscal associations, consolidating collaboration for risk management, and reassuring regional machineries for handling fiscal threats, can be accelerated. To develop infrastructural framework of the developing countries for the promotion of global imminent development is the most important need and requirement of OBOR (Wei, 2016). For this purpose, various steps should be taken to overcome the restrictions of business and investment, to flourish global economic progress and to encourage ease of trade( Figure 7). The initiative (OBOR) is incredible in size and the whole project is referred to the "CHINA'S MARSHAL PLAN". Behind this grand initiative, economic and strategic as well as historical factors are the different motives. It is basically the economic cooperation between China and Southeast Asia, the Middle East, South Asia, Europe and North Africa along the maritime Silk Road (Aris ,2016) .The BRI imagines a US\$1.3 trillion Chinese-led investment program creating a web of infrastructure, including railways, roads, telecommunications, ports and energy pipelines. This would serve to improve economic interconnectivity and facilitate development across East Africa, Eurasia and more than 60 partner countries. The final pillar on which China's claim to global leadership rests is BRI which is the development vehicle the "hardware of trade and investment" (Duan, 2016).

\section{Reforms in education sector of China (2011-2018)}

After stagnating during the Cultural Revolution, education is playing a crucial role in the modernization of the People' Republic of China. Its highly centralized structure is rapidly being dismantled; indeedheadlong decentralization is the key to Chinese reforms, say the authors. On 18 June 1985, the Chairman of the National Education Commission (Swanson \&Zhian, 1987). Education is slightly related to every walk of life and affect every section of society. Educational reforms not only involve elementary, secondary, and higher education, but also occupational and technical schools and education of adults. Educational reforms require not only the enthusiasm and initiatives of the education departments, but also the enthusiasm and initiatives of other departments, of further areas, of all walks of life. The new fame of 
education became seeming with the spare of the Ministry of Education with the National Education Commission( Li Peng, 1987). According to the Ministry of Education (1985), in a sequence of systemic educational reforms China has involved above the last 30 years. The aim of these reforms is to "improve the quality of the citizenry, produce more talents, and produce high quality talents." through movements in all dominions of governance, education, management, teacher preparation, financing, assessment and curriculum.

The importance of human capital/education on socioeconomic progress has been highlighted by several prior studies including Muhammad and Ather (2010), Baker et al. (2014), Azam and Ahmed (2015), Muhammad and Chandra (2014), Azam (2016), Khan and Haseeb (2017), Karim, and Khan (2018), and Khan and Irshad (2018). The educational spending are substantial indicator to measure the level of educational growth, whereas financial education spending plays vital role in the development of education in any country including China. The study finds that educational outlays and fiscal educational outlays shows positive effects on overall economic growth and development of China during the period from 2006 to 2014 (Li, 2017). The whole education system of China in the last recent decades has been the subject of record reforms. This improved and increased impact of educational reforms has provided substantial innovation and human resources, which smoothed progress in the cultural, social, economic, and political development (Uwamahoro, 2017) .

In 2017, China consumed about 4.3 trillion yuan (US\$675.3 billion) on education, a rise of $9.43 \%$ compared with 2016. Whereas, expenditures on pre-school education touched 325.5 billion yuan, up $16.11 \%$ from the last year. Investment in essential education totalled around 1.94 trillion yuan, a rise of 9.96 $\%$ year on year. Children in China getting nine years of essential education. While spending for high schools were 663.7 billion yuan, a rise of $7.82 \%$ from 2016, even though the data statistics for higher education surpassed 1.1 trillion yuan, up $9.72 \%$ from the last year i.e. 2016 (Xinhua, 2018). For the improvement of quality and fair education, China has issued a strategy on 
educational reforms. For this the General Office of the State and the Council Central Committee, thought that educational reform should upsurge people's "sense of acquisition." According to this report the largest public education sector in the world is only China such as in the end of 2016, China had 265 million students in schools. Similarly, the total numbers of schools are 512,000 in 2016 in the country. Figure 8 depicts government spending on education in China over the period of 2011 to 2018. The data demonstrates that expenditures on education increases every year (Xinhuan, 2019).

Public expenditure on education in China from 2011 to 2018 (in billion yua $n$ )

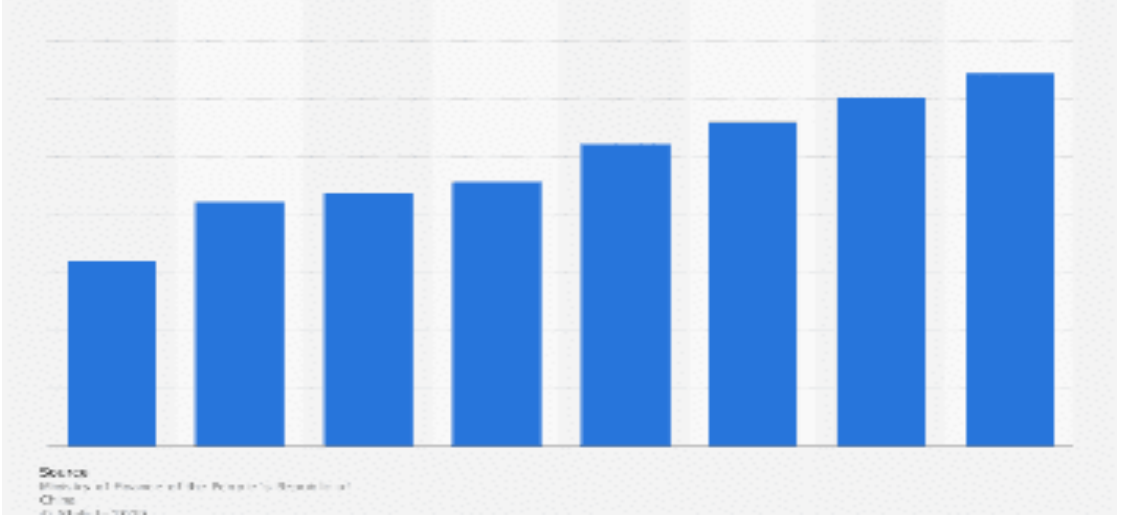

Figure 8

\section{Conclusion}

The China's Economic rise and market transition is one of the worlds most striking developmental story of the recent decade. The fastest Economic growth,the enduring political and educational developments and also the ever growing integration with the economies of the world stem from the china's " Reforms and opening policies adopted by the Chinese president Xi Jingping. China with the changing circumstances advanced lawbased governance and developed socialist democracy and also stepped up theinstitution building across the board to make the most integrated advances in the leadership of the party. The Chinese government empower the people to run the affairs of the country, improved the mechanisms by which the Party exercises leadership by $\mathrm{Xi}$ jinping. A Steady progress for enhancing 
socialist democracy ;socialist consultative democracy and intraparty democracy are flourishing in china.China's continues efforts for the rule of law to make the government, and society on the said patternshave been mutually reinforcing.

China is able to change the world because it has first changed itself. (Ling Zhijun).

The rise of China from avery poor developing country to a global economic power is spectacular from the last four decades. From 1979 to 2017, the China's gross domestic product (GDP) increase at the annual rate of nearly $10 \%$. According to the World Bankreport, China has lifted more than 800 million people out of poverty" and also experienced the fastest economic growth by a major global economy. Chinashowed dedication to the new development philosophy, right approach to economic development and the efforts to transform the growth model. The outcome of all the efforts are the constant progress and betterment in the quality and effect of development. The economic sector has maintained a medium-high growth rate, which has made China a leader among the leading global economies.China has given its utmost priority to education, introduce reform in education sector, develop education and modernize educationaccording to the wishes of the people. The new education policy implemented by the Chinese government, improved thestudents' well-rounded development, endorse fairness in education. China buildthe Chinese universities into the top-class universities of the world and also develop world-class disciplines to bring out the full potential of higher education.

A momentous step taken by China is the Belt and Road Initiative (BRI) to enhance its external cooperation and expand its opening-up to the world. This initiative o the Chinese governmentis unfolding day by day and will linkthe economy of China to the rest of the World. The modern china today's image presents a dual kind of image i.e. a society which is transforming itself through economic growth and through infrastructure investment that hope to become a global giant leader; oldest bureaucratic state of the world, with multiple traditions in its political, economic and educational spheres . 


\section{REFERENCES}

Aris, S. (2016), One Belt One Road: Chin's Vision of "Connectivity". CSS Analyses in the security policy.

Azam, M., (2019). Relationship between energy, investment, human capital, environment and economic growth in BRICS4. Environmental Science and Pollution Research, DOI: 10.1007/s11356-019-05934-0

Azam, M. (2016). Does governance and foreign capital inflows affect economic development in OIC countries? Journal of Economic Cooperation and Development, 37(4) 21-50

Azam, M. \& Ahmed, M. A. (2015). Role of human capital and foreign direct investment in promoting economic growth: evidence from Commonwealth of Independent States. International Journal of Social Economics, 42(2), 98-111.

Bakar, A N. A., Haseeb, M., \& Azam, M. (2014). The nexus between education and economic growth in Malaysia: cointegration and Toda-Yamamoto causality approach. Actual Problems of Economics, 12(162), 131-141

Barneet, D.(1986), Ten years after Mao, Foreign affairs magazine,China.

Berkelmans, L. and Wang, H. (2012), 'Chinese Urban Residential Construction to 2040', Reserve Bank of Australia, Research discussion paper.

Barro, R. J. (2016), Economic growth and convergence, applied especially to China, NBER Working Paper No. 21872, Cambridge, MA: National Bureau of Economic Research.

Cai, F. (2016), China's Economic Growth Prospects: From demographic dividend to reform dividend, Cheltenham, UK: Edward Elgar.

Cai, F., Garnaut, R. \& Song, L. (eds) (2013), China: A new model for growth and development, Canberra: ANU Press. International Monetary Fund (IMF). Available from: www.imf.org/external/ns/cs.aspx?id=29.

Chu, S. N. and Song, L. (2015), Promoting private entrepreneurship for deepening market reform in China: A resource allocation perspective, China \& World Economy.

Deng, X. (2014), Development is still priority, China Daily USA, 22

August.

Available

from: 
usa.chinadaily.com.cn/opinion/2014-

08/22/content_18468120.htm.

Denyer, S. (2018). Command and Control: China's Communist Party Extends Reach Into Foreign Companies, Washington Post USA.

Dreyer, J.(2008). China's Political System: Modernization and Tradition. Pearson Education, New York.

Duan, F. Ji, Q. Liu, B.Y. \& Fan, Y. (2018), Energy Investment Risk Assessment for Nations along China's Belt \& Road Initiative. Journal of Cleaner Production, 170, 535-547. Retrieved from URL https://doi.org/10.1016/j.jclepro.2017.09.152

Freeman, C. (2016). 'One Belt, One Road': what's in it for us? Remarks to a Workshop of the China Maritime Studies Institute.

Goh, E. (2016). Rising China's influence in developing Asia. Oxford University Press.USA

Hou, Q. (2017), CPC creates Xi Jinping thought on socialism with Chinese characteristics for a new era, Xinhuanet, 19 October. Available from: www. xinhuanet.com/english/201710/19/c_136689808.htmrowth', Economic Roundup, Issue 4.

Horsley, J.(2018) . What's So Controversial About China's New Anti-Corruption Body? The Diplomat Japan.

Heath, T.(2018), The consolidation of political powers in China under xi jingping. RAND Corporation, testimony presented to US china Economic Council.

Hernández, J.(2017). China's 'Chairman of Everything': Behind Xi Jinping's Many Titles," New York Times, USA.

Jiangyie (1985), "Work at Education as Important as Work on Economy: Interview with Mr. Li Peng, Vice Premier and Chairman of the State Education Commission," Chinese Education Daily, 16 July 1985, p. 1.

Karim, N. \& Khan, F., (2018). The effect of investment in education on socio-economic development of Pakistan. Pakistan Journal of Humanities \& Social Science Research 01 (02), 66-73

Khan, F., \&Irshad (2018). The effect of education and good trained teachers on students' performance. PUTAJ - Humanities and Social Sciences, 25(2), 93-99 
Khan F., \&Haseeb, M. (2017). Analysis of teacher training education program: a comparative study of Indonesia, Malaysia and Pakistan. Paradigms, 11(1), 13-17

Kuijis, L. \& Wang, T. (2005), 'China's Pattern of Growth: Moving to Sustainability and Reducing Inequality', The World Bank, Policy research paper 3767.

Kuijis, L. \& Wang, T. (2005), 'China's Pattern of Growth: Moving to Sustainability and Reducing Inequality', The World Bank, Policy research paper 3767.

Lin, J. and Wang, Y. (2017), Going Beyond Aid: Development cooperation for structural transformation, Cambridge: Cambridge University Pres.

Li, Y., (2017). The analysis on educational expenditure of China. 2017 3rd International Conference on Management Science and Innovative Education (MSIE 2017), pp-97-109

Lim Tai Wei, Henry Chan Hing Lee, Katherine Tseng Hui-Yu and Lim Wen Xin, (2016). China's One Belt One Road Initiative. London. Imperial College Press.

Landry, P., Lü, X. and Duan, H. (2017), Does performance matter? Evaluating political selection along the Chinese administrative ladder, American Political Science Review 51(8): 1074-105.

Miller,A.(2018). Only Socialism Can Save China; Only Xi Jinping Can Save Socialism," China Leadership Monitor, No. 56.

Miller, A. (2016). Projecting the next Politburo Standing Committee. China Leadership Monitor

Miller, A. (2016). 'Core' leaders, 'authoritative persons' and reform pushback. China Leadership Monitor.

Ministry of Education (1985), "Decisions on systemic educational reform (ZhonggongZhongyangGuanyuJiaoyuTizhi Gaige de Jueding)", available at: www.moe.edu.cn/edoas/website18/level3 $. j s p ? t a b l e n a m e \quad 1 / 4$ 208\&infoid $1 / 43318$

Muhammad, A.,, Khan, AQ., \&Ozturk, I., (2019). The effects of energy on investment, human health, environment and economic growth: Fresh empirical evidence from China. Environmental Science and Pollution Research, 26(11), 10816-10825 
Muhammad, A., \& Chandra, E. (2014). The role of Governance in economic development: Evidence from Some Selected Countries in Asia and the Pacific. International Journal of Social Economics,41(12):1265-1278

Muhammad, A., \&Ather M.A. (2010). Role of human capital in economic development: evidence from Pakistan: (19612009). Interdisciplinary Journal of Contemporary Research in Business, 2(4), 220-233

Oyeniran, R. \&Uwamahoro, E. (2017). Impacts of reforms in Chinese educational system. International Journal of Education, 9 (1), 20-31

Ping, H.(2018), Xi consolidation of power and the future of china. The Politic yale's Opportunities in Emerging Market China: Belt \& Road (2016). PWC. Accessed on 30 March, 2019. Retrieved from URL www.pwc.br.obor

Ronald, C. (1994). China's Struggle for the Rule of Law. St Martin's Press, New York.

Rogers, S. (2012). Bobby Kennedy on GDP: 'measures everything except that which is worthwhile', Guardian, 24 May. Available from: www.theguardian.com/news/ datablog/2012/may/24/robert-kennedy-gdp.

Shambaugh, D. ( 2017). China under Xi Jinping . East Asia forum USA.

Statista (2018). https://www.statista.com/statistics/455492/chinapublic-expenditure-on-education/

Swanson, D., A \& Zhian,, Z. (1987). Education Reform in China, Phi Delta Kappa International68, (5), 373-378.

Wang, Z., and A. Vangeli. (2016). The rules and norms of leadership succession in China: From Deng Xiaoping to xi Jinping and beyond. China Journal.

Wingender, P.(2018). Intergovernmental Fiscal Reform in China. IMF Working Paper.

Womack, B. 1982. Foundations of Mao Zedong's political thought, 1917-1935. Honolulu: University Press of Hawaii. 21.

Womack, B. 2010. Political reform and sustainable development in China. Fudan Journal of the Humanities and Social Sciences China. 
Womack, B. (2015). China and the future status quo. Journal of International Politics China

Weightman, C.W.(2018), Xi cracks down on local governments' compliance and creativity.East Asia Forum,USA.

Xinhua News Agency (2014). Party and government leading cadres selecting and appointing work regulations, Beijing: Central Government Portal. Available from: www.gov.cn/jrzg/2014-01/15/content_2567800.htm.

Xinhua (2018). China increases education spending in 2017. China daily News paper. Retrieved from http://www.chinadaily.com.cn/edu/201805/09/content_36166954.htm

Xinhuan News (2019), China Focus: Reform aims to improve educational fairness, quality. Available at http://www.xinhuanet.com//english/201709/25/c_136637048.htm

Yao, Y. (2009), The disinterested government: An explanation of China's economic success in the transitional period, Economic Review.

Yao, Y. (2018), Political equality, coalition formation and economic growth in autocracies, CCER Working Paper Beijing: China Center for Economic Research.

Yang, Z. ( 2015). Fragmented Authoritarianism-The Facilitator Behind the Chinese Reform Miracle: A Case Study in Central China. China Journal of Social Work.

Zhou,S.(2011), Trends in China's Political Reforms, Griffith Asia Institute, Australia.

Zhiyue, B.(2010). China's Elite Politics: Governance and Democratization. World Scientific Singapore. 